\title{
Population dynamics of Cylindrospermopsis raciborskii (Woloszynska) Seenayya \& Subba Raju, a Cyanobacteria toxic species, in water supply reservoirs in São Paulo, Brazil
}

\begin{abstract}
Marcina C. P. Gemelgo ${ }^{1}$, Célia L. Sant'Anna ${ }^{2,3}$, Andréa Tucci ${ }^{2}$ e Heloiza R. Barbosa ${ }^{1}$
Received: 28.12.2006; accepted: 27.06.2008

ABSTRACT - (Population dynamics of Cylindrospermopsis raciborskii (Woloszynska) Seenayya \& Subba Raju, a Cyanobacteria toxic species, in water supply reservoirs in São Paulo, Brazil). The Guarapiranga and Billings reservoirs are main sources of public water supply to millions of people in the city of São Paulo, Brazil. They have been under intense antropic action as a result of domestic, industrial, farm and livestock waste being dumped in the reservoirs. Cyanobacteria develop very well in such an environment, producing blooms that are most often toxic. Cylindrospermopsis raciborskii (Woloszynska) Seenayya \& Subba Raju is a toxic species which is rapidly spreading all over the world and is abundant in the studied reservoirs. The goal of the study was to follow the year-round variation of the C.raciborskii population density and to correlate it with selected environmental factors. Samples were collected monthly on the surface of the water column and studied under a binocular optic microscope, whereas quantitative studies were carried out under an inverted microscope, according to the Utermöhl method. Among the phytoplankton community, organisms of the Cyanobacteria Class were represented by the greatest population density $\left(\right.$ cells $\left.\mathrm{mL}^{-1}\right)$. Cylindrospermopsis raciborskii was one of the abundant species in the Billings reservoir, both in the dry and rainy season. The principal environmental factors that influenced $C$. raciborskii population dynamics were water temperature, high $\mathrm{pH}$ values and low euphotic zone values.
\end{abstract}

Key words: bloom, Cylindrospermopsis raciborskii, eutrophic reservoirs, phytoplankton

RESUMO - (Dinâmica populacional de Cylindrospermopsis raciborskii (Woloszynska) Seenayya \& Subba Raju, uma espécie tóxica de Cyanobacteria em reservatórios de abastecimento, SP, Brasil). Os Reservatórios Guarapiranga e Billings integram uma das principais fontes de abastecimento público da cidade de São Paulo, suprindo água para milhões de pessoas. Esses reservatórios estão sofrendo intensa ação antrópica devido a despejos domésticos, industriais e agropecuários. Em tais ambientes, Cyanobacteria desenvolvem-se intensamente, formam florações que, na maioria das vezes são tóxicas. Cylindrospermopsis raciborskii (Woloszynska) Seenayya \& Subba Raju é uma espécie tóxica e em expansão em todo o planeta, sendo uma das espécies abundantes nos reservatórios estudados. O objetivo do trabalho foi acompanhar a variação da densidade da população de C. raciborskii ao longo do ano, relacionando com os fatores ambientais estudados. As coletas mensais, realizadas na superfície da coluna d'água, foram analisadas ao microscópio óptico binocular e a análise quantitativa foi feita ao microscópio invertido, conforme método de Utermöhl. A maior densidade (cel $\left.\mathrm{mL}^{-1}\right)$ da comunidade fitoplanctônica observada, foi representada por organismos da classe Cyanobacteria, em ambos os reservatórios. Cylindrospermopsis raciborskii foi uma das espécies abundantes no Reservatório Billings, nas estações seca e chuvosa. Os principais fatores ambientais que influenciaram na dinâmica de $C$. raciborskii foram: temperatura da água e pH elevados, assim como baixos valores da zona eufótica.

Palavras-chave: Cylindrospermopsis raciborskii, fitoplâncton, florações, reservatórios eutróficos

\section{Introduction}

The Guarapiranga and Billings reservoirs are components of one of the main sources of public water supply in the metropolitan area of the city of São Paulo, providing water to millions of people and hundreds of industrial plants. Those reservoirs, like all reservoirs located near large urban centers, suffer intense antropic action due mostly to the discharge of household and industrial waste water and fertilizer, and to deforestation of surrounding areas.

According to Zagatto et al. (1997), high nutrient concentration, mostly phosphates and nitrogen compounds, added to light intensity, water temperature

1. Universidade de São Paulo, Instituto de Ciências Biomédicas, Departamento de Microbiologia, ICB II, Av. Prof. Lineu Prestes, 1374, 05508-900 São Paulo, SP, Brasil

2. Instituto de Botânica, Caixa Postal 3005, 01061-970 São Paulo, SP, Brasil

3. Corresponding author: csantana@ig.com.br 
(between 15 and $30{ }^{\circ} \mathrm{C}$ ) and $\mathrm{pH}$ values between 6 and 9 , together favor the multiplication of phytoplankton species, leading to blooming.

Cyanobacteria blooms have several environmental, social and economic consequences on continental waters around the globe and their ability to produce toxins also causes important losses to the public health sector. The competitive success of Cyanobacteria is based on their adaptive strategies, both physiologic and ecologic, which enable them to remain in the euphotic zone and to regulate their position within the water column in order to take greater advantage of light and nutrients (Klemer 1991).

Cylindrospermopsis raciborskii (Woloszynska) Seenayya \& Subba Raju, in particular, has been widely studied (Isvánovics et al. 2000, Padisák 1997, Padisák et al. 2003, Sant'Anna et al. 2006) because it to produces blooms that interfere with water utilization and contains hepatotoxins (cyclic guanidinic alkaloid) and neurotoxins (carbamate-type alkaloids). The cylindrospermopsin-type hepatotoxin inhibits protein synthesis, thus damaging the structure and leading to necrosis of the liver, as well as of the kidneys, heart, lungs and gastric mucosa. The saxitoxin-type neurotoxin (known as Paralytic Shellfish Poison or PSP in short) blocks sodium channels in nerve cells, leading to paralysis, hypotension and respiratory failure (Kuiper-Goodman et al. 1999, Sant'Anna et al. 2006).

Padisák (1997) analyzed data about the occurrence, ecology, migratory patterns and distribution of Cylindrospermopsis raciborskii on four continents, and observed its dominance in different environments, resulting from its many abilities to compete and to resist herbivore organisms. According to Padisák (1997), the ecologic success of $C$. raciborskii is attributed to different factors such as floatability, tolerance to low light levels and high capacity to assimilate ammonium and phosphate. The occurrence and migratory patterns of $C$. raciborskii suggest that its wide distribution through tropical, subtropical and temperate zones is due to its great ability to disperse through water bodies and through birds and to its resistant akinetes. In view of the above and of the environmental and public health problems $C$. raciborskii has been causing, Komárek \& Komárková (2003) emphasize the importance of carrying out detailed studies of the autoecology of this species.

Several studies show Cylindrospermopsis raciborskii is widely distributed in Brazil but studies of its population dynamics are lacking. Among them it can be found the researches of Branco \& Senna (1991, 1994), which studied taxonomic aspects of Cylindrospermopsis raciborskii in Paranoá Lake (center-west region of Brazil), Bouvy et al. (1999), which registered the dynamics of this species in an eutrophic reservoir in Pernambuco (northeast of Brazil), Komárková et al. (1999) which studied its morphology in a south Brazil coastal lagoon, and finally, Tucci \& Sant'Anna (2003) which studied $C$. raciborskii weekly variation in an eutrophic reservoir in São Paulo.

Regarding the reservoirs analyzed in the course of this study there are even fewer studies on $C$. raciborskii dynamics and the only existing work is that of Souza et al. (1998). In that study the phytoplankton of a branch of the Billings reservoir was analyzed and the authors observed that $C$. raciborskii was the dominant species throughout the period studied.

Thus, in view of the problems caused by this species and the importance of the reservoirs as sources of water provision to millions of people, the goal of this study was to analyze the population dynamics of $C$. raciborskii during a full seasonal cycle in two tropical water supply reservoirs, and to determine its relationship to the environmental factors that influenced the development of the organism.

\section{Material and methods}

The Guarapiranga and Billings reservoirs are part of the High Tietê basin and are located in the São Paulo, SP metropolitan area, in Brazil (table 1).

Samples of material were collected on the surface of the water, every month, from February 2002 to January 2003. A specific sampling point was selected for each reservoir, at the location where water is captured for supplying to the consumer public. The following measurements were made: water temperature, transparency (Secchi Disk), euphotyc zone (Cole 1994), turbidity (Turbiditymeter), dissolved oxygen (Oxymeter OXI-197 TWT), conductivity (Conductivitymeter) and $\mathrm{pH}$. The collected material was analyzed as follows: ammonium - NBR 10560, ABNT (1988); nitrate - 4500 $\mathrm{NO}_{3}{ }^{-}$, APHA (1998); nitrite - 4500NO ${ }_{2}^{-}$, APHA (1998); total phosphorus 4500P, APHA (1998) and chlorophyll $a$ (CETESB 1990).

Samples used for qualitative analysis of the phytoplankton were collected by means of a plankton net with a $20 \mu \mathrm{m}$ mesh size, and fixed in $4 \%$ formaldehyde. Analysis of the material was made 
Table 1. General characteristics of the Guarapiranga and Billings Reservoirs (municipality of São Paulo).

\begin{tabular}{lcc}
\hline & Guarapiranga & Billings \\
\hline Coordinates & $23^{\circ} 43^{\prime} \mathrm{S}$ and $46^{\circ} 32^{\prime} \mathrm{W}$ & $23^{\circ} 47^{\prime} \mathrm{S}$ and $46^{\circ} 40^{\prime} \mathrm{W}$ \\
Area & $33 \mathrm{Km}^{2}$ & $120 \mathrm{Km}^{2}$ \\
Maximum profundity & $13 \mathrm{~m}$ & $18 \mathrm{~m}$ \\
Water retention time & 185 days & 720 days \\
\hline
\end{tabular}

under a binocular microscope whose optical train was fitted with a light chamber, a measuring eyepiece and an epifluorescence device. The following classification systems were used: Komárek \& Anagnostidis (1989, 1999, 2005) for Cyanobacteria, Van den Hoek et al. (1995) for Chlorophyceae and Bourrelly (1985) for the remaining classes.

Samples gathered for quantitative analysis of the phytoplankton were collected by means of a Van Dorn bottle and preserved in a $1 \%$ acetic lugol solution. Cell counts were established according to the method described by Utermöhl (1958), using an inverted Carl Zeiss microscope, under $400 \times$ magnification. Sedimentation time of the samples was three hours for each centimeter of height of the chamber, according to the criterion proposed by Lund et al. (1958). The sedimentation chamber used was a $2 \mathrm{~mL}$ one. Counting was carried out by means of horizontal and vertical transects and the minimum number of counted fields per sedimentation chamber followed the stabilization curve of the number of species, which was obtained based on new species added to each counted field.

The dominant species were considered with superior densities to $50 \%$ of the total density of the
sample.The abundant species were those with superior densities to the medium density of each sample (Lobo \& Leighton 1986).

Statistical analysis of results was made by multivaried analysis of data. Principal Components Analysis (PCA) was used in order to determine the variability of environmental data, in relation to the months studied (McCune \& Mefford 1997).

\section{Results}

Abiotic variables - Data on physical and chemical variables are shown in figure 1 and 2 for the Guarapiranga and Billings reservoirs, respectively. They are transparency, euphotic zone, rainfall, water temperature, dissolved oxygen, $\mathrm{pH}$, conductivity, turbidity, ammonium, nitrates, nitrites and total phosphorus.

The Principal Components Analysis (PCA), applied to both reservoirs studieds herein, showed the two aquatic environments as two different units, grouping $68 \%$ of the total variability in the two first axes (it represents table 2, figure 3 ). Axis 1 summarized the variability for both systems, separating the reservoirs,

Table 2. Pearson and Kendall correlation between environmental variables on the two first axes of the PCA ordination, as observed in the two reservoirs, Guarapiranga and Billings, during the period covered by the study $(n=24)$.

\begin{tabular}{llcc}
\hline Environmental variables & Abbreviations & \multicolumn{2}{c}{ Principal Components } \\
\cline { 3 - 4 } & & -0.152 & Axis 2 \\
\hline Water temperature & $\mathrm{WT}$ & $\mathbf{0 . 8 9 4}$ & $\mathbf{- 0 . 9 5 8}$ \\
Euphotic zone & Euphz & $\mathbf{- 0 . 8 0 4}$ & -0.133 \\
Turbidity & Turb & $\mathbf{- 0 . 8 8 2}$ & 0.139 \\
Conductivity & $\mathrm{Cond}$ & $\mathbf{- 0 . 8 6 8}$ & 0.235 \\
$\mathrm{pH}$ & $\mathrm{pH}$ & $\mathbf{- 0 . 6 8 8}$ & -0.164 \\
Dissolved oxygen & $\mathrm{DO}$ & 0.431 & 0.025 \\
Ammonium & $\mathrm{NH}_{4}^{+}$ & $\mathbf{0 . 7 6 7}$ & 0.345 \\
Nitrate & $\mathrm{NO}_{3}{ }^{-}$ & $\mathbf{- 0 . 5 9 0}$ & 0.132 \\
Total phosphorus & $\mathrm{TP}^{-}$ & $\mathbf{- 0 . 8 3 9}$ & -0.053 \\
Chlorophyll $a$ & $\mathrm{Chlo} a$ & & 0.099 \\
\hline
\end{tabular}


according to the environmental variables, as well as in gradient seasonal tracking the axis 2: on the positive side of Axis 1 (53\% of explained variance) the sampling units of June, July, August and October were ordered, associated to the high values of nitrite and euphotic zone, in the Guarapiranga reservoir. On the negative side of Axis 1 the sampling units of February, June, August, October, November, December and
January, during which the highest of conductivity, turbidity, dissolved oxygen, total phosphorus and $\mathrm{pH}$ values, in the Billings reservoir. On the negative side of Axis 2 (15\% of explained variance) the sampling units of March, April and January associated to the high values of temperature of the water, in both reservoirs.

Phytoplankton community - Quantitative

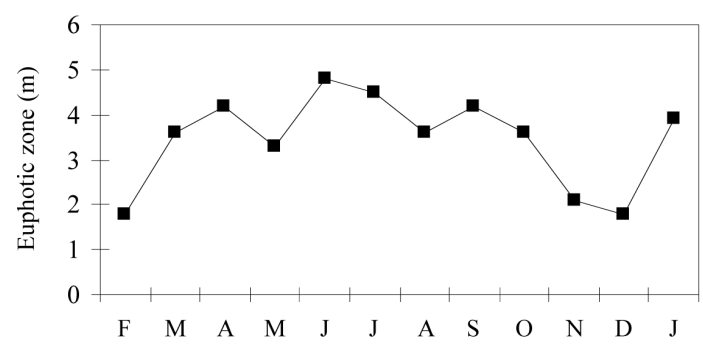

A

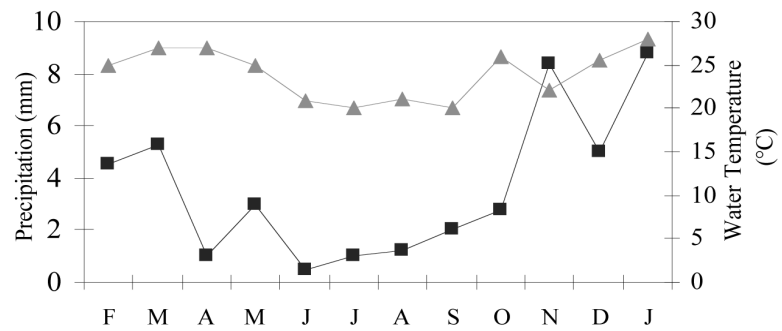

B

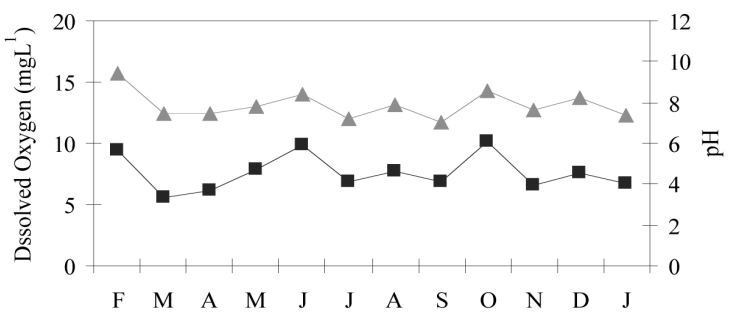

C

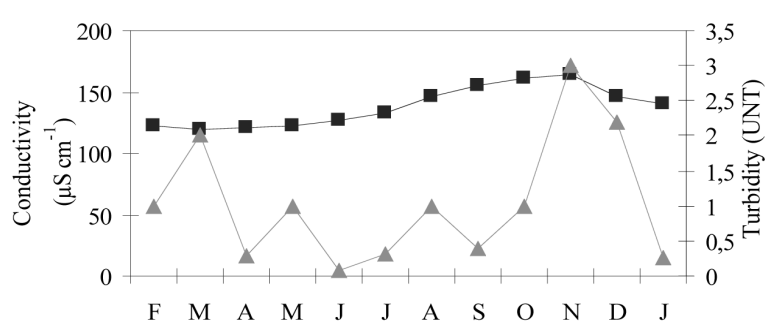

D

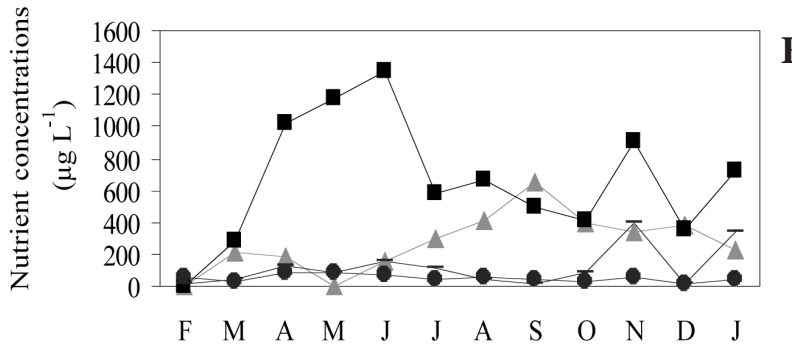

Figure 1. Monthly variation of physical and chemical parameters of Guarapiranga reservoir: euphotic zone (m, - $\mathbf{-}$ ); precipitation (mm,

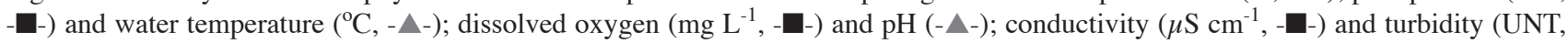
- $\mathbf{\Delta}$-) in A, B, C and D; nutrient concentrations (- $\boldsymbol{\Delta}$ - ammonium, - $\boldsymbol{-}$ - nitrate, $\mathbf{-}$ - nitrite, - $\mathbf{O}$ - phosphorus total) in E. Months are represented from February (F) through December (D) 2002 and January (J) 2003. 
analyses of samples from the Guarapiranga reservoir yielded 178 taxa distributed among nine classes. In the Billings reservoir 142 taxa were identified, distributed among eight classes. Chlorophyceae was the class qualitatively best represented in both Reservoirs, with 88 taxa (49\%) in the Guarapiranga Reservoir and with 61 taxa (42\%) in the Billings Reservoir.

Cyanobacteria was the second best represented class in each of the Reservoirs, with 34 taxa (20\%) in the

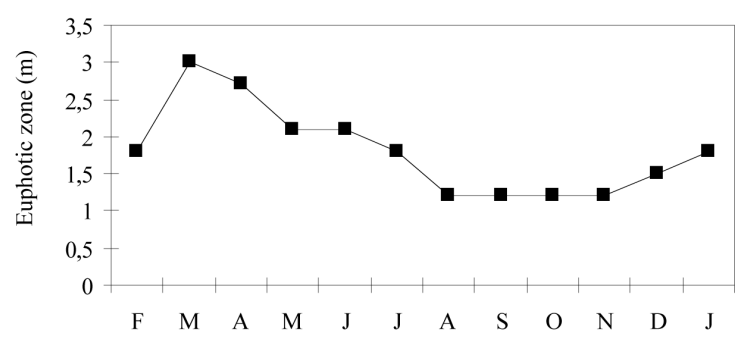

A
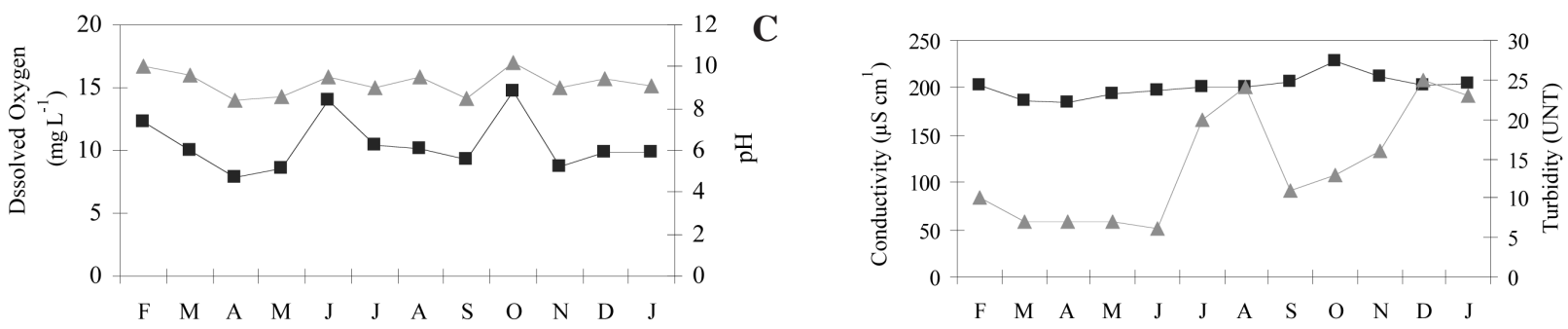

D

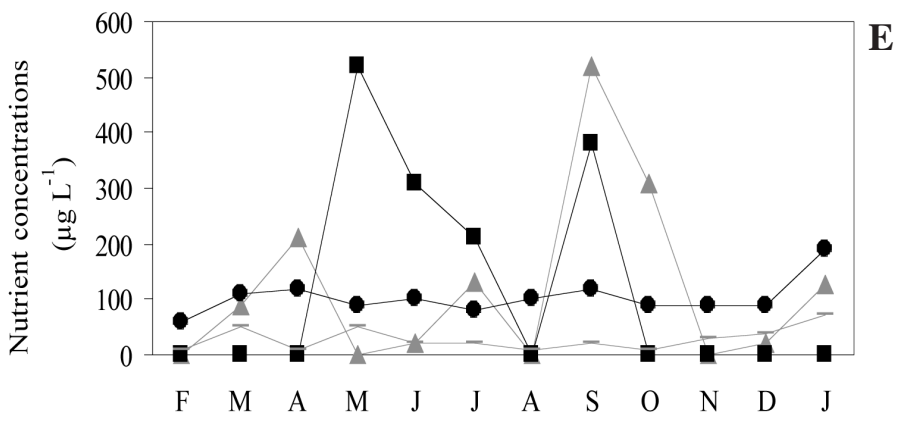

Figure 2. Monthly variation of physical and chemical parameters of Billings reservoir: euphotic zone (m; - $\mathbf{-}$ ); precipitation (mm; - $\mathbf{0}$ )

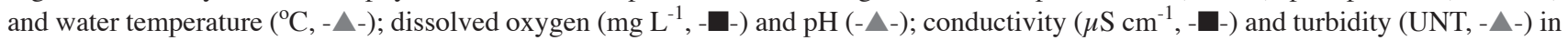
A, B, C and D; nutrient concentrations (- $\mathbf{A}$ - ammonium, - $\mathbf{-}$ - nitrate, _- nitrite, - - - phosphorus total) in E. Months are represented from February (F) through December (D) 2002 and January (J) 2003. 


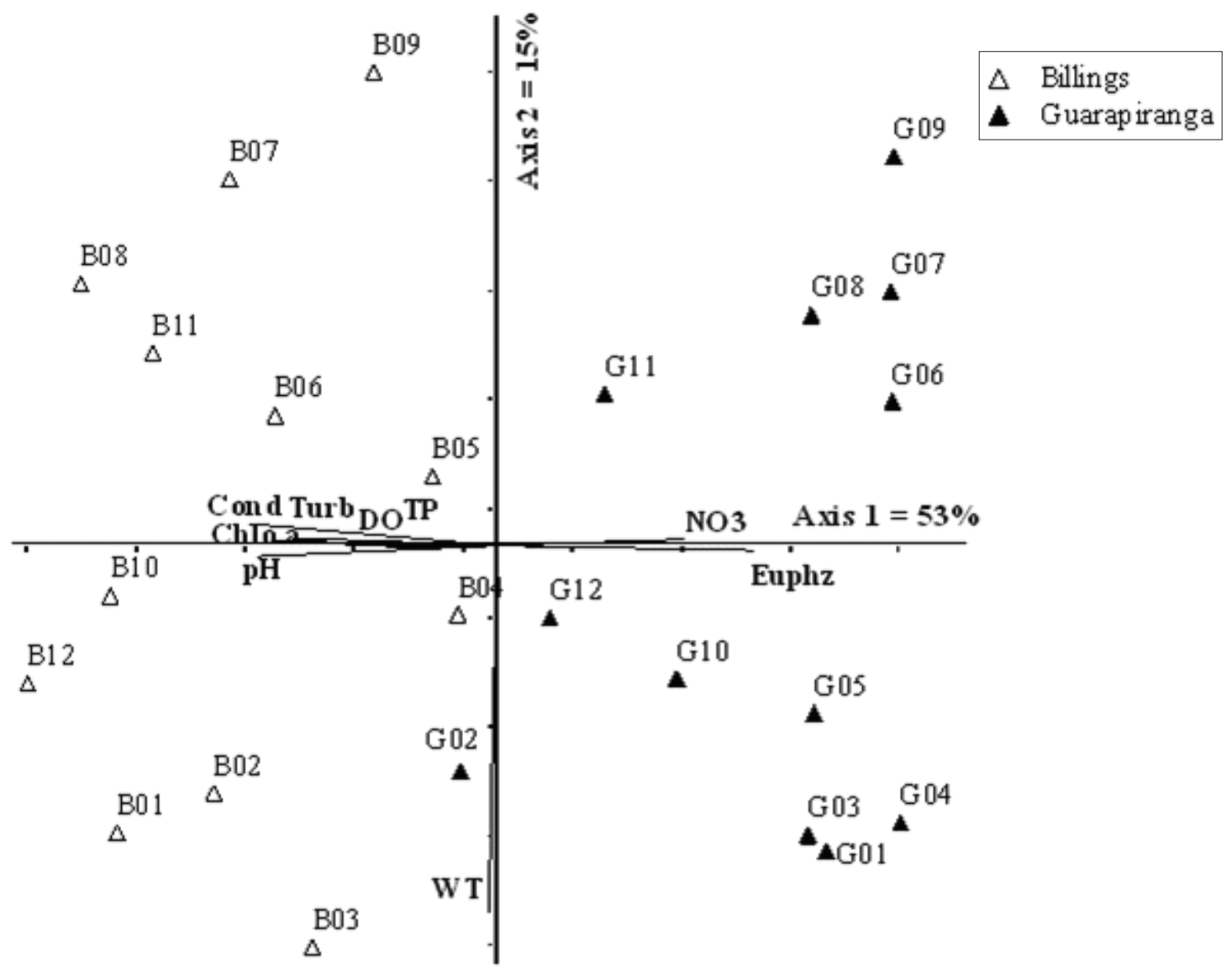

Figure 3. Biplot ordination resulting from the PCA applied to the sampling units with the physical, chemical and biological variables, in the Billings and Guarapiranga reservoirs. Months are represented from B02=February, B03=March, B04=April, B05=May, B06=June, B07=July, B08=August, B09=September, B10=October, B11=November, B12=December of 2002 and B01=January of 2003; G02=February, G03=March, G04=April, G05=May, G06=June, G07=July, G08=August, G09=September, G10=October, G11=November, G12=December of 2002 and G01=January of 2003. Abbreviations for environmental variables are presented in table 2.

Cylindrospermopsis raciborskii (Woloszynska) Seenayya \& Subba Raju (figure 5) is characterized by single, straight or curved trichomas, cells with aerotopes, terminal heterocytes and cylindrical, subterminal akinetes.

When comparing the density of $C$. raciborskii (figure 6) with densities of other Cyanobacteria in the Guarapiranga reservoir, C. raciborskii occurred in February, May, November, December 2002 and January 2003 and was one of the abundant species in February, reaching $20 \%$ of the total density of all Cyanobacteria. In the Billings reservoir it occurred during the entire period of the study and was abundant in the dry (May, June and August 2002) and rainy (November and December 2002, and January 2003) seasons (figure 6). The figure 6 show a comparison of C. raciborskii density with that of other Cyanobacteria species and of clorophyll $a$, for both reservoirs. In figure 7, the annual densities of phytoplankton classes are compared to the density of $C$. raciborskii, the latter being larger than the density of all other phytoplankton classes.

\section{Discussion}

The composition of the phytoplankton community in the two reservoirs, Guarapiranga and Billings, revealed that the Chlorophyceae class, mostly represented by the Chlorococcales order, was the one with the largest number of taxa. These results seem to apply to other eutrophized reservoirs in Brazilian tropical regions and are consistent with those from several other authors: Beyruth (1996), Bouvy et al. (1999), Matsuzaki (2004), Sant'Anna 

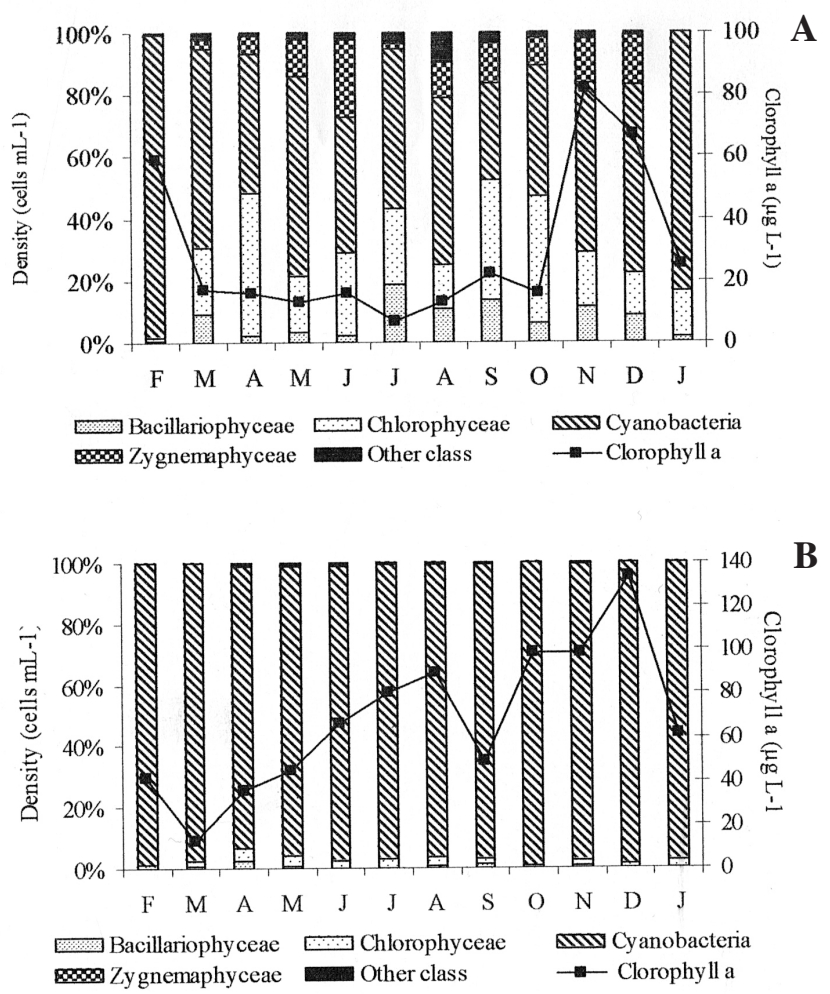

Figure 4. Contribution of phytoplankton classes to total density and cloroplyll $a$ in the Guarapiranga (A) and Billings (B) reservoirs. Months are represented from February (F) through December (D) 2002 and January (J) 2003.

et al. (1989, 1997), Silva (1999) and Tucci \& Sant'Anna (2003).

The Principal Component Analysis (PCA) showed that the physical and chemical variables that interfered in the temporal reservoirs dynamics were: water temperature, euphotic zone, turbidity, conductivity, $\mathrm{pH}$ and dissolved oxygen. Moreover, high nitrate and total phosphorus were available, allowing ideal conditions to phytoplankton blooms on both reservoirs. The PCA has also confirmed the difference between the reservoirs, showed by their separation through axis 1 , also by a seasonal gradient through axis 2.

Moreover, the observed high availability of total phosphorus, ammonium, nitrate and nitrite, help create ideal conditions for the formation of blooms by Cyanobacteria. Similar results were obtained by Huszar et al. (2000) in eight tropical lakes situated in different tropical regions of Brazil.

The results of the present study confirm the high population density of the phytoplankton community in the Guarapiranga reservoir, the same observation

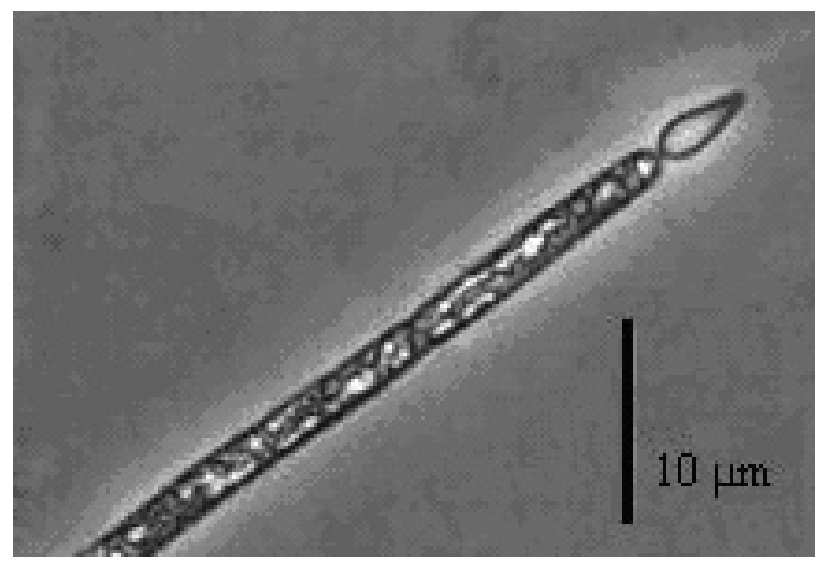

Figure 5. Photomicrograph of Cylindrospermopsis raciborskii with terminal heterocyte.

having been made by Beyruth et al. (1997), who attributed the problem to the eutrophication of the water body. In our study, values upwards of $10^{6}$ cells $\mathrm{mL}^{-1}$ were detected, mainly for Cyanobacteria. Important results obtained in the present study show that, starting in 2002, the density of Cylindrospermopsis raciborskii (Wolosz.) Seen. \& Subba Raju, was high. This species had not been found in this reservoir before 2000 (C. L. Sant'Anna, unpublished data).

The present research also shows an increase in the number of taxa of the Cyanobacteria class in relation to the number found by Beyruth (1996), who identified 14 taxa of that class. This present study shows that the number of taxa have risen to 34 and including the presence of Cylindrospermopsis raciborskii. This fact is probably due to urban human settlements in the reservoir area, a phenomenon that has been growing in the last years and leads to eutrophication (Beyruth et al. 1997). Urbanization, as well as other human activities, when carried out improperly or in the absence of adequate planning, cause sometimes irreversible damage to the capacity of water sources (Capobianco \& Whately 2002). Moreover, due to water shortages affecting Guarapiranga reservoir, it was necessary to build a canal linking the Taquacetuba branch of the Billings reservoir to the Guarapiranga reservoir, in order to solve the issue of water deficit in the latter. Pumping operations in the canal started in August 2000 (Beyruth 2000, Capobianco \& Whately 2002, Tundisi 2003).

This study shows that subsequently to the pumping of the water, several species of Cyanobacteria were found in Guarapiranga Reservoir, including Cylindrospermopsis raciborskii, which had not been reported in that Reservoir. 
In the Billings Reservoir, Cyanobacteria were dominant and abundant throughout the period of study. This fact is related to the physiologic and ecologic strategies employed by Cyanobacteria and that offer great competitive advantage where the environment is highly charged with phosphorus (Padisák 1997). Chorus \& Bartram (1999) cited the different strategies allowing for the survival of those organisms, such as nutrient availability that leads to their rapid development, the presence of a mucilaginous sheath and of aerotopes for better floatability within the water column, thus facilitating light exposure, temperatures above $25^{\circ} \mathrm{C}$ and low light tolerance in order to prevent the growth of other species.

The Billings reservoir has been considered eutrophic and hipereutrophic for decades, with frequent Cyanobacteria bloom formation (Branco 1986). Souza et al. (1998) studied one of the branches of the Billings Reservoir called Rio Pequeno, and observed the dominance of Cylindrospermopsis raciborskii. Lagos et al. (1999) cultivated $C$. raciborskii from water samples of the Taquacetuba branch of Billings Reservoir and showed its ability to produce saxitoxin. Cylindrospermopsis raciborskii is considered a species whose distribution is expanding in different regions of the world (Padisák 1997). Apparently, the release of toxins by $C$. raciborskii and by other Cyanobacteria species has an allelopathic effect in the water, thus inhibiting the growth of other species of the phytoplankton community and allowing for the rapid development of $C$. raciborskii and for its impact on the utilization of the water supply reservoirs (Yunes et al. 2003).

There seems to be no nitrogen fixation by Cylindrospermopsis raciborskii in either of the studied reservoirs since in the Guarapiranga reservoir no heterocyte (the cells type where nitrogen fixation occurs) was found on the analyzed trichomas. In the Billings reservoir only $1.4 \%$ of trichomas showed heterocytes. The fact that only a few trichomas presented heterocytes may be explained by the high concentrations of nitrogen observed in the studied environment (figures 1E, 2E) which makes this nutrient a non-limiting factor, in this case, to the development of $C$. raciborskii.

It was observed that, in the Guarapiranga reservoir, the environmental factors that most interfered with the dynamics of Cylindrospermopsis raciborskii were high values for water temperature (between 20 and 28 ${ }^{\circ} \mathrm{C}$ ), rainfall (between 0.5 and $9 \mathrm{~mm}$ ) and $\mathrm{pH}$ (between 7 and 10), as well as low values for euphotic zone (between 1.8 and $4.8 \mathrm{~m}$ ), those conditions coinciding with the periods of greatest density of $C$. raciborskii (figure 6).

High values for water temperature, $\mathrm{pH}$ and conductivity, as well as low numbers for euphotic zone were also found in the Billings reservoir (figure 2). An important factor to be considered is the water retention time (table 1, which is much higher for the Billings Reservoir and which certainly favored dominance by Cyanobacteria, including Cylindrospermopsis raciborskii, during the analyzed period. A comparison of the data here reported with those reported by Bouvy et al. (1999), Branco \& Senna (1994), Huszar et al. (2000), Komárková et al. (1999), Souza et al. (1998) and by Tucci \& Sant'Anna (2003) shows there is the similarity among data from several different regions in Brazil.

Due to eutrophic conditions of Paranoá Lake, in Brasília, in the center-west region of Brazil, $C$. raciborskii was responsible for bloom formation in that lake (Branco \& Senna 1994). Bouvy et al. (1999) analyzed the species making up the phytoplankton, as well as their seasonal succession, of an eutrophized
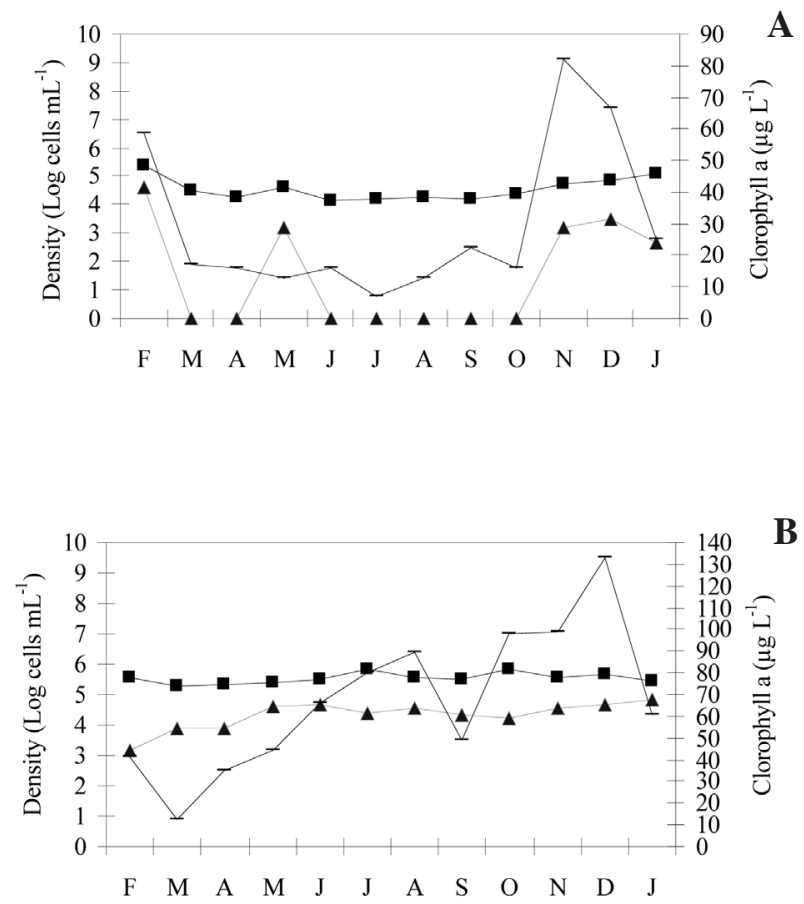

Figure 6. Density of Cylindrospermopsis raciborskii (- $\mathbf{\Delta}-$ ), other Cyanobacteria (-口-) and chlorophyll $a$ (-) in the Guarapiranga (A) and Billings (B) reservoirs. Months are represented from February (F) through December (D) 2002 and January (J) 2003. 

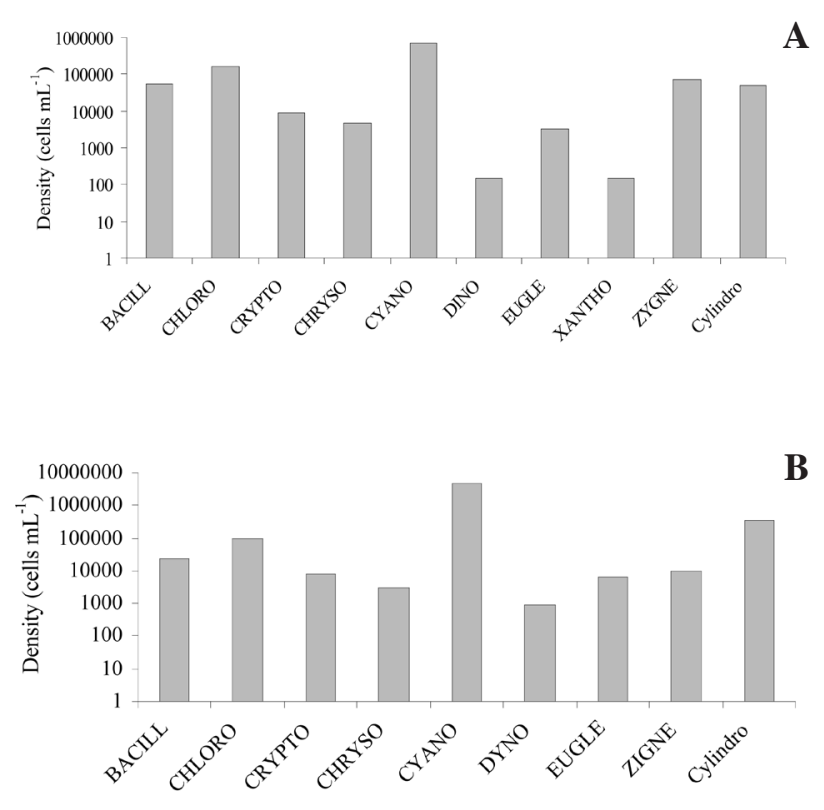

Figure 7. Annual density of the different phytoplankton classes and of Cylindrospermopsis raciborskii in the Guarapiranga (A) and Billings (B) reservoirs.

reservoir in Pernambuco, in the northeast region of Brazil. The authors observed that neurotoxic $C$. raciborskii was the dominant species throughout the period of the study. Komárková et al. (1999) observed, while studying a coastal lagoon in the south of Brazil, that $C$. raciborskii may present great morphologic variety (straight, curved or spiral shapes) and that the species was the dominant one during periods of high temperature, low nitrogen concentration and high phosphorus concentration. Tucci \& Sant'Anna (2003) studied the weekly variation of $C$. raciborskii in an eutrophic reservoir in São Paulo, in Brazil, and correlated the high density of that organism to high temperature and $\mathrm{pH}$, high concentration of chlorophyll $a$, low water transparency, low concentrations of free carbonic gas and ammonium.

The present study, results shows that the ideal conditions for the development of Cylindrospermopsis raciborskii were water temperature above $20^{\circ} \mathrm{C}$, low levels of transparency (between 0.4 and 1.0 $\mathrm{m}$ ) and euphotic zone (between 1.2 and $4.5 \mathrm{~m}$ ), $\mathrm{pH}$ values around 8 and high concentrations of available ammonium ions $\left(700 \mu \mathrm{g} \mathrm{L}^{-1}\right)$ and nitrate $(1,400 \mu \mathrm{g}$ $\left.\mathrm{L}^{-1}\right)$. Besides the above ideal conditions, the transfer of water from the Billings reservoir to the Guarapiranga reservoir certainly favored the appearance of $C$. raciborskii in the Guarapiranga reservoir, since there are reports about the occurrence of the species in the Billings reservoir dating back the 1990s (Carvalho et al. 1997). In Guarapiranga reservoir, the previous studies, do not mention the occurrence of $C$. raciborskii (Matsuzaki 2007).

\section{Acknowledgments}

The authors wish to thank Companhia de Tecnologia de Saneamento Ambiental (CETESB) for providing the samples and physical and chemical data; Dr. Luciana Retz de Carvalho (Instituto de Botânica de São Paulo, Brazil) for her assistance with the intepretation of chemical variables. They are also grateful to Antonio J. Gemelgo and Tiago P. Melo for reviewing the texts and to Dr. Marcells Bouquet for the English translation. This study is part of the Monitoramento Especial da Qualidade das Águas do Sistema Produtor Billings-Taquacetuba/Guarapiranga (Special Monitoring of the Waters of the BillingsTaquacetuba/Guarapiranga Supply System).

\section{Literature cited}

APHA. 1998. Standard methods for the examination of water and wastewater. 20 ed. American Public Health Association APHA, AWWA, Washington D.C., pp. 1-1268.

ABNT. 1988. NBR 10560. Associação Brasileira de Normas Técnicas, Brasília, pp. 1-897.

Beyruth, Z. 1996. Comunidade fitoplanctônica da Represa de Guarapiranga: 1991-92. Aspectos ecolocógicos, sanitários e subsídios para reabilitação da qualidade ambiental. Tese de Doutorado, Faculdade de Saúde Pública da Universidade de São Paulo, São Paulo.

Beyruth,Z. 2000. Periodic disturbances, trophic gradient and phytoplankton characteristics related to cyanobacterial growth in Guarapiranga Reservoir, São Paulo State, Brazil. Hydrobiologia 424: 51-65.

Beyruth, Z., Caleffi, S., Zanardi, E., Cardoso, E. \& Rocha, A.A. 1997. Water quality of Guarapiranga Reservoir, São Paulo, Brazil, 1991-1992. Verhandlungen der Internationalen Vereinigung für Theoretische und Angeivandte Limnologie 26: 675-683.

Bourrelly, P. 1985. Les algues d'eau douce: initiation à la systématique, 3: les algues blenes et rouges, les Eugléniens, Peridiniens, et Cryptomonadines, v. 3. N. Boubée, Paris.

Bouvy, M., Molica, R., De Oliveira, S., Marinho, M. \& Beker, B. 1999. Dynamics of a toxic cyanobacterial bloom (Cylindrospermopsis raciborskii) in a shallow reservoir in the semi-arid region of northeast Brazil. Aquatic Microbial Ecology 20: 285-297. 
Branco, S.M. 1986. Hidrobiologia aplicada à engenharia sanitária. v. 1. CETESB/ASCETESB, São Paulo.

Branco, C.W.C. \& Senna, P.A. 1991. The taxonomic elucidation of the Paranoá Lake (Brasília, Brazil) problem: Cylindrospermopsis raciborskii. Bulletin du Jardin Botanique National de Belgique 61: 85-91.

Branco, C.W.C. \& Senna, P.A. 1994. Factors influencing the development of Cylindrospermopsis raciborskii and Microcystis aeruginosa in the Paranoá Reservoir, Brasília, Brazil. Algological Studies 75: 85-96.

Capobianco, J.P.R. \& Whately, M. 2002. Billings 2000: ameaças e perspectives para o maior reservatório de água da região metropolitana da bacia hidrográfica da Billings no período 1989-99. Instituto Socioambiental, São Paulo.

Carvalho, M.C., Coelho-Botelho, M.J., Lamparelli, M.C., Roquetti-Humaitá, M.H., Salvador, M.E.P., Souza, R.C.R. \& Truzzi, A. 1997. Spatial and temporal variations of chlorophyll $a$, plankton and some physicochemical factors at Billings Complex, São Paulo, Brazil. Verhandlungen der Internationalen Vereinigung für theoretische und angeivandte Limnologie 26: 452-457.

Chorus, I. \& Bartram, J. 1999. Toxic Cyanobacteria in water. A guide to their public health consequences, monitoring and management. E \& FN Spon, London.

Cole, G. 1994. Textbook of limnology. 4 ed. Waveland Press, Illinois.

CETESB. 1990. Determinação de pigmentos fotossintetizantes: clorofila-a, b e c e feofitina-a Método de ensaio. Norma Técnica L5.306. Companhia de Tecnologia de Saneamento Ambiental, São Paulo.

Huszar, V.L.M., Silva, L.H., Marinho, M., Domingos, P. \& Sant'Anna, C.L. 2000. Cyanoprokaryote assemblages in eight productive tropical Brazilian waters. Hydrobiologia 424: 67-77.

Isvánovics, V., Shafik, H.M., Présing, M. \& Juhos, S. 2000. Growth and phosphate uptake kinetics of the cyanobacterium, Cylindrospermopsis raciborskii (Cyanophyceae) in throughflow cultures. Freshwater Biology 43: 257-275.

Klemer, A.R. 1991. Effects of nutritional status on cyanobacteria buoyancy bloom, and dominance, with special reference to inorganic carbon. Canadian Journal of Botany 69: 1133-1138.

Komárek, J. \& Anagnostidis, K. 1989. Modern approach to the classification system of Cyanophytes 4 Nostocales. Algological Studies 56: 247-345.

Komárek, J. \& Anagnostidis, K. 1999. Cyanoprokaryota, 1.Teil: Chroococcales. In: H. Ettl, G. Gärtner, H. Heynig \& D. Möllenhauer (eds.). Süßwasserflora von Mitteleuropa. v. 19/1. Gustav Fischer Verlag, Jena, pp. 1-548.

Komárek, J. \& Komárková, J. 2003. Phenotype diversity of the cyanoprokaryotic genus Cylindrospermopsis
(Nostocales); review 2002. Czech Phycology, Olomouc 3: 1-30.

Komárek, J. \& Anagnostidis, K. 2005. Cyanoprokaryota, 2: Oscillatoriales. In: B. Büdel, L. Krienitz, G. Gärtner, \& M. Schagerl (eds.). Süßwasserflora von Mitteleuropa. Vol. 19/2. Elsevier GmbH, München, pp. 1-758.

Komárková, J., Silva, R.L. \& Senna, P.A. 1999. Extreme morphology of Cylindrospermopsis raciborskii (Nostocales, Cyanobacteria) in the Lagoa do Peri, a freshwater coastal lagoon, Santa Catarina, Brazil. Algological Studies 94: 207-222.

Kuiper-Goodman, T., Falconer, I. \& Fitzgerald, J. 1999. Human health aspects. In: I. Chorus \& J. Bartram (eds.). Toxic Cyanobacteria in Water. A guide to their public health consequences, monitoring and management. E \& FN Spon, London, pp. 114-153.

Lagos, N., Onodera, H., Zagatto, P.A., Andrinolo, D., Azevedo, S.M.F.Q. \& Oshima, Y. 1999. The first evidence of paralytic shellfish toxins in the freshwater cyanobacterium Cylindrospermopsis raciborskii, isolated from Brazil. Toxicon 37: 1359-1373.

Lobo, E. \& Leighton, G. 1986. Estruturas de las fitocenosis planctônicas de los sistemas de desembocaduras de rios y esteros de la zona central de Chile. Revista de Biologia Marinha 22: 143-170.

Lund, J.W.G., Kipling, C. \& Lecren, E.D. 1958. The inverted microscope method of estimating algal number and the statistical basis of estimating by counting. Hydrobiologia 11: 143-170.

Matsuzaki, M. 2007. Transposição das águas do braço Taquacetuba da represa Billings para a represa Guarapiranga: aspectos relacionados à qualidade de água para abastecimento. Tese de Doutorado, Faculdade de Saúde Pública da Universidade de São Paulo, São Paulo.

Matsuzaki, M., Mucci, J.L.N. \& Rocha, A.A. 2004. Phytoplankton community in a recreational fishing lake, Brazil. Revista de Saúde Pública 38: 679-686.

McCune, B. \& Mefford, M.J. 1997. PC-ORD Multivariate Analysis of Ecological Data, Version 3.1. MjM Software Design, Gleneden Beach, pp. 1-47.

Padisák, J. 1997. Cylindrospermopsis raciborskiiI (Woloszynska) Seenayya et Subba Raju, an expanding, highly adaptive cyanobacterium: worldwide distribution and review of its ecology. Archiv für Hydrobiologie 107: 563-593.

Padisák, J., Borics, G., Fehér, G., Grigorszky, I., Oldal, I., Schmidt, A. \& Zámbóné-Doma, Z. 2003. Dominant species, functional assemblages and frequency of equilibrium phases in late summer phytoplankton assemblages in Hungarian small shallow lakes. Hydrobiologia 502: 157-168.

Sant'Anna, C.L., Azevedo, M.T.P. \& Sormus, L. 1989. Fitoplâncton do Lago das Garças, Parque Estadual 
das Fontes do Ipiranga, São Paulo, SP, Brasil: Estudo taxonômico e aspectos ecológicos. Hoehnea 16: 89131.

Sant'Anna, C.L., Sormus, L., Tucci, A. \& Azevedo, M.T.P. 1997. Variação sazonal do fitoplâncton do Lago das Garças, São Paulo, SP, Brasil, Hoehnea 24: 67-86.

Sant'Anna, C.L., Azevedo, M.T.P., Agujaro, L.F., Carvalho, M.C., Carvalho, L.R. \& Souza, R.C.R. 2006. Manual ilustrado para identificação e contagem de cianobactérias planctônicas de águas continentais brasileiras. Interciência, Rio de Janeiro.

Silva, L.H.S. 1999. Fitoplâncton de um reservatório eutrófico (Lago Monte Alegre), Ribeirão Preto, São Paulo, Brasil. Revista Brasileira de Biologia 59: 281-303.

Souza, R.C.R., Carvalho, M.C. \& Truzzi, A.C. 1998. Cylindrospermopsis raciborskii (Wolosz.) Seenaya and Subba Raju (Cyanophyceae) dominance and a contribution to the knowledge of Rio Pequeno arm, Billings reservoir, Brazil. Environmental Toxicology and Water Quality 13: 73-81.

Tucci, A. \& Sant'Anna, C.L. 2003. Cylindrospermopsis raciborskii (Wloszynska) Seenayya and Subba Raju
(Cyanobacteria): variação semanal e relações com fatores ambientais em um reservatório eutrófico, São Paulo, SP, Brasil. Revista Brasileira de Botânica 26: 97-112.

Tundisi, J.G. 2003. Água no Século XXI: enfrentando a escassez.. Rima, São Carlos.

Utermöhl, H. 1958. Zur Vervollkommung der Quantitativen Phytoplankton Methodik. Mitteilungen Internationale Vereinigung fur Theoretische und Angewandte Limnologie 9: 1-38.

Van den Hoek, C., Mann, D.G. \& Jahns, H.M. 1995. Algae: an introduction to phycology. University Press, Cambridge.

Yunes, J.S., Cunha, N.T., Barros, L.P., Proença, L.A.O. \& Monserrat, J.M. 2003. Cyanobacterial neurotoxins from Southern Brazilian freshwaters. Comments on Toxicology 9: 103-115.

Zagatto, P.A., Aragão, M.A., Carvalho, M.C. \& Souza, R.C.R. 1997. Manual de prientação em casos de florações de algas tóxicas: um problema ambiental e de saúde pública. Companhia de Tecnologia de Saneamento Ambiental, São Paulo. 